\title{
IMPLEMENTASI PENDIDIKAN KARAKTER DI SMP NEGERI 8 DAN SMP NEGERI 9 PURWOKERTO
}

\author{
Tutuk Ningsih, Zamroni, Darmiyati Zuchdi \\ Universitas Negeri Yogyakarta, Universitas Negeri Yogyakarta \\ tutukstain@yahoo.com, amronihardjowirono@yahoo.com
}

\begin{abstract}
Abstrak
Penelitian ini bertujuan untuk menemukan dan mendeskripsikan; (1) implementasi pendidikan karakter (IPK) di SMP Negeri 8 dan SMP Negeri 9 Purwokerto; (2) peran kepala sekolah, guru, dan siswa dalam IPK; dan (3) aktualisasi nilai-nilai karakter dalam IPK. Metode yang digunakan dalam penelitian ini merupakan metode kualitatif dengan pendekatan kualitatif-naturalistik.Teknik pengumpulan data yang digunakan adalah pengamatan partisipan, wawancara mendalam, dan dokumentasi. Analisis data menggunakan model interaktif Miles dan Huberman. Berdasarkan hasil penelitian ditarik kesimpulan berikut ini. (1) Implementasi pendidikan karakter yang dilakukan melalui pola kegiatan terpadu antara kegiatan intrakurikuler dan ekstrakurikuler (2) Implementasi pendidikan karakter yang dilakukan oleh kepala sekolah, guru, dan siswa mempunyai peranan yang positif dalam pembentukan kultur sekolah yang berkarakter. Peran kepala sekolah, guru, dan siswa dalam IPK diwujudkan dalam: (a) peran kepala sekolah sebagai motivator, pemberi contoh keteladanan, pelindung, penggerak kegiatan, perancang kegiatan, pendorong, dan pembimbing; (b) peran guru sebagai pendidik, pengasih, dan pengasuh; dan (c) peran siswa sebagai subjek didik dan pelaksana kegiatan di sekolah. (3) Aktualisasi nilai-nilai karakter dalam IPK cenderung mengacu pada prinsip ABITA (Aku Bangga Indonesia Tanah Airku) berbasis kebangsaan dan religius yang meliputi 18 nilai karakter, yaitu: (a) nilai religius, (b) kejujuran, $(c)$ demokratis, $(d)$ tanggung jawab, $(e)$ disiplin, $(f)$ peduli lingkungan, $(g)$ peduli sosial, $(h)$ kerja keras, $(i)$ mandiri, $(j)$ cinta tanah air, $(k)$ semangat kebangsaan, $(l)$ rasa ingin tahu, $(m)$ gemar membaca, $(n)$ menghargai prestasi, (o) cinta damai, $(p)$ bersahabat/komunikatif, $(q)$ toleran, dan $(r)$ kreatif. (4) Terdapat persamaan dan perbedaan dalam IPK di kedua SMP tersebut. Persamaannya adalah mengacu pada nilai-nilai yang ada pada prinsip ABITA, perbedaannya kalau di SMP Negeri 8 melaksanakan 12 nilai karakter dan kegiatan pelajaran sekolah setiap pagi diawali dengan baca Alquran pada jam ke-0, sedangkan SMP Negeri 9 Purwokerto melaksanakan 18 nilai karakter sesuai prinsip ABITA sebagai pilot projek Kemdikbud yang kegiatan pelajaran dimulai setiap pagi diawali dengan "Salam ABITA", menyanyikan lagu kebangsaan, dan kegiatan kebersihan lingkungan sekolah.
\end{abstract}

Kata kunci: pendidikan karakter, sekolah menengah pertama.

\section{THE IMPLEMENTATION OF CHARACTER EDUCATION IN $8^{\text {TH }}$ STATE JUNIOR HIGH SCHOOL AND $9^{\text {TH }}$ STATE JUNIOR HIGH SCHOOL PURWOKERTO}

\section{Abstract}

The research in general was to found and to describe: (1) the implementation of character education in the $8^{\text {th }}$ and the $9^{\text {th }}$ State Junior High School Purwokerto; (2) the role of the principals, the teachers and the students in the implementation of character education; and (3) the actualization of character values in the implementation of character education. The method that the researchers employed was a qualitative one by means of naturalistic-qualitative approach. Then, the data gathering that the researchers employed were participatory observation, in-depth interview and documentation. For the data analysis, the researchers employed the Miles and Huberman interactive model. Based on the results, the researchers drew the following conclusion: (1) the implementation of character education was performed by the school in the integrated pattern between the intracurricular and extracurricular activities; and (2) the implementation of character education performed by the principals, the teachers and the students had a positive role in the formation of characterized school cultures; (3) the actualization of character values in the implementation of character education tended to refer to the principles of ABITA (Aku Bangga Indonesia Tanah Airku or I am proud of Indonesia My Mother Land) that had been based on the characters of nationality and religiosity and that included 18 character values namely: $(a)$ religiosity; $(b)$ honesty; $(c)$ democracy; $(d)$ responsibility; $(e)$ discipline; (f) environmental care; $(g)$ social care; $(h)$ hardworking; $(i)$ independence; $(j)$ nationalism; $(k)$ spirit of nationality; $(l)$ curiosity; $(m)$ reading; (n) achievement appreciation; (o) love for peace; $(p)$ friendship/communication; $(q)$ tolerance; and $(r)$ creativity; and (4) There had been similarities and differences in the implementation of character education in both schools. The similarities were that the implementation of character educations referred to the values contained in the principles of ABITA. On the other hand, the differences were that 8th State Junior High School implemented 12 character values for the character education and in each morning the teaching-learning activities were started by the reading of Al-Qur'an in the 0 period; meanwhile, 9th State Junior High School implemented 18 character values according to the ABITA model as a pilot project of the Ministry of National Education and the teaching-learning activities were started with ABITA Greetings and school cleaning activities. The roles of the principals, the teachers and the students were actualized in: (a) being a motivator, role mdel, protector, activity promotor, activity creator, encourager and mentor (for the principals; (b) in being an educator, a loving person and a caretaker (for the teachers); and (c) in being a learning subject and activity performed in the school.

Keyword: character education, junior high schools 


\section{PENDAHULUAN}

Penerapan kurikulum berbasis kompetensi telah berhasil meningkatkan kualitas ilmu pengetahuan dan teknologi, tetapi di pihak lain kompetensi dalam bidang moral dan karakter terabaikan. Padahal, karakter merupakan suatu fondasi bangsa yang sangat penting dan perlu ditanamkan sejak dini kepada anak-anak. Menurut Sri Sultan HB X (2012, p.3), hal ini disebabkan oleh ukuranukuran dalam pendidikan tidak dikembalikan pada nilai-nilai keluhuran budi pekerti dan karakter peserta didik, tetapi kecenderungan masyarakat yang bersifat rasional-kapitalisme setelah peserta didik menyelesaikan proses pendidikan dapat segera mendapatkan pekerjaan sesuai kompetensi dalam bidang ilmu pengetahuan dengan teknologi yang umumnya dikembalikan pada kebutuhan pasar (permintaan) di dunia kerja.

Implementasi pendidikan karakter di sekolah sampai saat ini masih belum mampu menunjukkan hasil yang signifikan, sebagaimana yang dimaksudkan dalam tujuan pendidikan nasional yaitu mengembangkan kemampuan dan membentuk watak serta peradaban bangsa yang bermartabat dalam rangka mencerdaskan kehidupan bangsa, bertujuan untuk berkembangnya potensi peserta didik agar menjadi manusia yang beriman dan bertakwa kepada Tuhan Yang Maha Esa, berakhlak mulia, sehat, berilmu, cakap, kreatif, mandiri, dan menjadi warga negara yang demokratis serta bertanggung jawab (UU Sisdiknas 2003 Pasal 2). Parkay \& Beverly (1998, p.280) mengemukakan kaitan antara pembelajaran nilai dan (penalaran) moral dengan pendidikan karakter sebagai berikut: "One approach to teaching values and moral reasoning is known as character education, that stresses a development of students "good character" yang artinya: salah satu pendekatan untuk mengajarkan nilai-nilai dan penalaran moral dikenal sebagai pendidikan karakter, yang menekankan pada pengembangan karakter siswa yang baik.

Upaya yang cukup strategis untuk membantu penanggulangan krisis nilai-nilai karakter dapat ditempuh dengan berbagai alternatif terutama melalui pendidikan, baik melalui proses pendidikan di sekolah maupun di luar sekolah, atau pendidikan formal dan non-formal di masyarakat. Pendidikan karak- ter merupakan proses untuk mengembangkan pada diri setiap peserta didik kesadaran sebagai warga bangsa yang bermartabat, merdeka dan berdaulat serta berkemauan untuk menjaga dan mempertahankan kemerdekaan dan kedaulatan tersebut (Zamroni, 2011, p.12). Lebih lanjut Montesquieu sebagaimana yang dikutip Zamroni (2011, p.12) menegaskan bahwa karakter bangsa sangat berkaitan dengan hukum, bentuk dan perilaku pemerintahan yang ada. Karakter bangsa akan tercermin bagaimana warga bangsa tunduk dan patuh pada hukum yang berlaku. Demikian pula karakter bangsa akan tercermin pada bagaimana warga bangsa memahami atas bentuk dan implementasi pemerintahan yang ada. Masyarakat berkarakter akan selalu memberikan dukungan apabila pemerintah berjalan di atas rel yang benar. Sebaliknya warga bangsa akan bereaksi dan memberikan kritik manakala pemerintah menyeleweng dari garis-garis yang telah ditetapkan (Zamroni, 2011, p.24).

Hasan M.T. (2003, p.152) menyebutkan bahwa salah satu fenomena yang sekarang sedang berkembang adalah menipisnya disiplin moral. Hal ini terjadi hampir di semua lapisan masyarakat. Banyak orang yang tidak peduli lagi terhadap sikap dan perilakunya. Gejala penyalahgunaan sikap rasional, tekni$\mathrm{kal}$, dan profesional menjadi gaya hidup (yang hanya mempertanyakan: apa yang dapat dilakukan?) mengabaikan sikap moral dan etis (yang mempertanyakan: apa yang baik dilakukan?) dan apalagi sikap spiritual yang relegius (yang mempertanyakan: apa yang halal dilakukan? Lickona (1991, pp.20-22) dalam bukunya yang berjudul "education for character: how our schools can teach respect and respon-sibility" menyatakan bahwa salah satu alasan mengapa pendidikan karakter itu diperlukan bagi suatu bangsa adalah adanya kenyataan bahwa kekurangan yang paling mencolok pada diri anak-anak adalah dalam hal nilai-nilai moral. Pada umumnya guru mereka mengatakan berawal dari masalah keluarga. Orang tua yang kurang perhatian menjadi salah satu alasan utama mengapa sekolah sekarang merasa terdorong untuk terlibat dalam pendidikan nilai-nilai moral dan karakter. Lebih lanjut Lickona (1991, pp.3759) menegaskan bahwa proses pendidikan karakter dan moral yang efektif, di samping dilaksanakan oleh sekolah juga diperlukan dukungan dari pihak keluarga. Dewantara 
(2008, p.26) menjelaskan bahwa pendidikan adalah upaya untuk memajukan perkembangan budi pekerti (kekuatan batin), pikiran (intelektual) dan jasmani anak-anak. Pendidikan menurutnya adalah untuk memajukan kesempurnaan hidup, yakni kehidupan dan penghidupan anak yang selaras dengan alam dan masyarakat. Lebih lanjut Dewantara (1955, pp.358-365) mengatakan bahwa metode pengajaran dan pendidikan yang lebih cocok adalah berdasarkan sistem among dengan pola asih, asah dan asuh. Metode ini meliputi: kepala, hati, dan panca indera.

Secara toritis, penelitian ini diharapkan dapat menghasilkan suatu bentuk aktualisasi nilai-nilai karakter dalam proses pembelajaran pendidikan karakter yang efektif serta bermanfaat untuk menambah khasanah ilmu pengetahuan dalam bidang pendidikan terutama meningkatkan nilai-nilai pendidikan karakter peserta didik. Secara praktis, hasil penelitian ini dapat bermanfaat untuk sekolah sebagai bahan pertimbangan dalam pembelajaran setingkat SMP dan dinas yang terkait dalam mengambil kebijakan secara tepat sehingga keberadaan lembaga sekolah SMP dapat menjadi lebih baik dan para siswanya menjadi lulusan yang bermutu unggul, sekaligus memiliki karakter kebangsaan religius yang kuat.

\section{METODE PENELITIAN}

Jenis penelitian ini adalah penelitian kualitatif-naturalistik. Subjek penelitian ini adalah kepala sekolah, guru, dan siswa di SMP Negeri 8 dan SMP Negeri 9 Purwokerto. Penentuan subjek penelitian dengan cara purposive sampling. Sedangkan objek penelitian adalah kultur sekolah, dan aktivitas kepala sekolah dalam IPK di sekolah dan kerangka konseptual pelaksanaan pendidikan karakter di sekolah. Teknik pengumpulan data yang digunakan adalah pengamatan partisipan, wawancara mendalam, dan dokumentasi. Instrumen utama dalam penelitian ini adalah peneliti sendiri. Uji keabsahan data dilakukan dengan cara: perpanjangan pengamatan, meningkatkan ketekunan, trianggulasi, analisis kasus negatif, dan member checking. Analisis data menggunakan model interaktif Miles dan Huberman melalui empat tahapan, yang meliputi: pengumpulan data, reduksi data, penyajian data, dan pengambilan kesimpulan.

\section{HASIL PENELITIAN DAN PEMBAHASAN}

\section{Implementasi Pendidikan Karakter di SMP Negeri 8 dan SMP Negeri 9 Purwokerto.}

Implementasi pendidikan karakter di SMP Negeri 8 dan SMP Negeri 9 Purwokerto dilaksanakan dengan sistem terpadu melalui pola kegiatan intrakurikuler dan ekstrakurikuler.

\section{Kegiatan Intrakurikuler}

Implementasi pendidikan karakter dalam kegiatan intrakurikuler melalui kegiatan PBM memiliki peran yang sangat penting dan positif dalam menanamkan nilai-nilai karakter pada peserta didik di kedua SMP Negeri Purwokerto tempat penelitian. Pada kedua sekolah tempat penelitian, pendidikan karakter tidak diselenggarakan secara sistematis pada mata pelajaran yang berdiri sendiri, tetapi secara substansi implementasi pendidikan karakter sudah terlihat dari beberapa kegiatan yang dilakukan sekolah seperti guru mengaitkan materi pelajaran dengan pembinaan karakter peserta didik seperti pengembangan sikap disiplin dalam mengikuti kegiatan belajar mengajar, memotivasi siswa dalam belajar merupakan bagian dari pembinaan karakter untuk membangun etos kerja tinggi. Ada beberapa nilai karakter dan moral yang dapat ditanamkan kepada perserta didik pada saat berlangsungnya proses belajar mengajar, yaitu sebagai berikut: (1) pada jam ke-0 setiap pagi, di SMP Negeri 8 Purwokerto siswa beragama Islam baca tadarus/asmaul husna, sedang yang beragama Hindu (terdapat 1 orang) dengan mempraktikkan nilai-nilai catur veda yang termaktub dalam kitab Veda; sedangkan di SMP Negeri 9 Purwokerto diawali dengan salam ABITA dan menyanyikan lagu-lagu kebangsaan; (2) dalam proses pembelajaran berlangsung, guru mengintegrasikan pada sub pokok bahasan yang sesuai dengan nilai karakter dan moral yang ada dalam proses PBM; (3) sebelum dimulai proses PBM selalu diawali dengan berdo'a sesuai agama dan kepercayaan masing-masing, demikian juga pada saat mengakhiri pelajaran; (4) pengaturan jadwal kebersihan kelas; (5) menerapkan aturan tata tertib sekolah berikut sangsi bagi yang melanggar; dan (6) penanaman nilainilai kedisiplinan, keteladanan, dan rasa tanggung jawab, termasuk tidak mencontek pada 
saat ulangan (test), serta mengerjakan tugastugas PR oleh guru.

\section{Kegiatan Ekstrakurikuler}

Kegiatan ekstrakurikuler yang diselenggarakan oleh sekolah memiliki peran penting dan positif dalam mendukung proses penanaman nilai-nilai karakter warga sekolah, baik malalui kegiatan yang berkaitan dengan sosial keagamaan maupun sosial kemasyarakatan. Berbagai macam kegiatan ekstrakurikuler di SMP Negeri 8 Purwokerto dan SMP Negeri 9 Purwokerto menjadi bagian yang tidak terpisahkan dari peroses pembentukan karakter peserta didik walaupun secara eksplisit tidak dijelaskan namun secara implisit bahwa tujuan kegiatan ekstrakurikuler merupakan bagian dari pembinaan karakter peserta didik. Pelaksanaan pendidikan karakter melalui kegiatan ekstrakurikuler, terutama yang dilakukan oleh siswa-siswa antara meliputi, (a) kegiatan Baca Tulis Al-Qur'an (BTA) dan sholat dhuhur berjamaah, (b) kegiatan olah raga, (c) kegiatan Pramuka, dan (d) kegiatan PMR. Nilai-nilai karakter melalui kegiatan ekstrakurikuler ini adalah menekankan pada nilainilai karakter dan moral sebagai berikut: (1) tanggung jawab, (2) komunikatif, (3) kejujuran, (4) religius, (5) peduli sosial, (6) menghargai prestasi, (7) kreatif, (8) mandiri, (9) bersahabat/komunikatif, (10) demokrasi dan (11) disiplin.

Berdasarkan hasil observasi lapangan menunjukkan bahwa di kedua sekolah (SMP Negeri 8 dan SMP Negeri 9 Purwokerto) tersebut memandang penting kegiatan ekstrakurikuler sebagai kegiatan yang dapat membentuk karakter peserta didik serta dapat mendukung nilai-nilai karakter dan moral dalam pelaksanaan kegiatan intrakurikuler, sehingga tujuan pendidikan sebagaimana yang diamanatkan dalam Undang-Undang No. 20 Tahun 2003 tentang Sistem Pendidikan Nasional dapat terwujud dengan menghasilkan siswa yang berkarakter dan moral berbudi pekerti luhur.

\section{Peran Kepala Sekolah, Guru, dan Siswa dalam Implementasi Pendidikan Karakter di SMP Negeri 8 dan SMP Negeri 9 Purwokerto.}

Implementasi pendidikan karakter di SMP Negeri 8 dan SMP Negeri 9 Purwokerto berdasarkan hasil penelitian menunjukkan bahwa warga sekolah (kepala sekolah, guru, dan siswa) memiliki pemahaman yang sama dan berpengaruh positif tentang pentingnya pendidikan karakter di sekolah dalam upaya membangun karakter peserta didik. Peran kepala sekolah, guru, dan siswa dalam mengimplementasikan pendidikan karakter di SMP Negeri 8 dan SMP Negeri 9 Purwokerto dibahas masing-masing dalam uraian berikut ini.

\section{Peran Kepala Sekolah}

Kepala sekolah sebagai pemimpin puncak di lembaga SMP Negeri 8 dan SMP Negeri 9 Purwokerto memiliki peran yang sangat penting dan berpengaruh positif dalam mengimplementasikan pendidikan karakter di sekolah pada jenjang atau tingkat SMP. Adapun peran kepala sekolah baik di SMP Negeri 8 maupun di SMP Negeri 9 Purwokerto tersebut berpengaruh positif terhadap pelaksanaan implementasi pendidikan karakter di sekolah. Ada tujuh peran yang sangat dominan yang ditunjukkan oleh kepala sekolah dalam mengimplementasikan pendidikan karakter di sekolah, yaitu sebagai: (1) motivator, (2) pemberi contoh keteladanan, (3) pelindung, (4) penggerak kegiatan, (5) perancang kegiatan, (6) pendorong, dan (7) pembimbing.

Sebagai motivator dinyatakan bahwa kepala sekolah sebagai pemimpin puncak di sekolah merasa memiliki kewajiban untuk memotivasi semua warga sekolah agar selalu dapat mengimplementasikan nilai-nilai karakter sesuai dengan filsafat Pancasila dan nilainilai religius. Kepala sekolah berkewajiban memberikan contoh keteladanan kepada semua warga sekolah seperti yang dilakukan oleh kepala sekolah di kedua SMP Negeri tersebut misalnya, datang ke sekolah lebih awal, disiplin, dan bertanggung jawab dalam melaksanakan tugas pekerjaan, dengan maksud agar menjadi panutan yang baik bagi semua warga sekolah. Kepala sekolah juga memiliki tanggung jawab dalam hal membuat perencanaan dan program kegiatan sekolah bersama dengan wakil kepala sekolah, dan dewan guru lainnya. Hal ini dimaksudkan agar semua kegiatan yang akan dilaksanakan oleh sekolah dapat terprogram dengan baik sehingga memudahkan dalam merealisaikan program kerja di sekolah, termasuk dalam mengimplementasikan nilai-nilai karakter yang berwawasan religius di sekolah. Kepala sekolah juga berperan sebagai pelindung, dalam arti melin- 
dungi warga sekolah dalam merealisasikan program kerja sekolah agar bisa terarah dan terprogram sebagaimana yang telah direncanakan dalam program kegiatan sekolah. Sebagai pelindung juga harus mampu mengayomi semua warga sekolah apabila mendapatkan permasalahan yang dialaminya yang terkait dengan sosial kemasyarakatan. Dalam rangka untuk meningkatkan rasa kekeluargaan ini misalnya yang dilakukan oleh kepala sekolah bersama guru dan karyawan di kedua SMP Negeri tersebut yaitu antara lain melakukan silahturrahim berkunjung ke rumah guru atau karyawan yang sedang mendapatkan musibah atau sakit, berkunjung pada saat ada acara kelahiran anak, dan hajatan lainnya. Wujud peran kepala sekolah sebagai pelindung kegiatan maupun sebagai pengayom warga sekolah secara berkeadilan dan kesetaraan tersebut pada hakikatnya juga merupakan implementasi dari praktik pendidikan karakter di sekolah. Sebagai penggerak kegiatan dalam arti bahwa pada saat pelaksanaan kegiatan berlangsung, kepala sekolah di kedua SMP tersebut ikut berperan serta dalam setiap kegiatan yang dilaksanakan bersama warga sekolah lainnya. Hal tersebut menunjukkan bahwa kepala sekolah selalu mengikuti dan berperan aktif. Tindakan tersebut menunjukkan bahwa keberhasilan sekolah adalah murupakan tanggung jawab bersama warga sekolah. Peran aktif kepala sekolah dalam kegiatan semacam ini ternyata ikut membangkitkan semangat warga sekolah. Mereka merasa dihargai, dan bahkan adanya kepedulian guru dan karyawan ikut berperan aktif dalam mewujudkan kultur sekolah yang berkarakter dan religius. Sebagai pembimbing dalam arti bahwa kepala sekolah mampu memberikan bimbingan secara berkeadilan dan kesetaraan tanpa membedakan agama dan asal usul, serta latar belakang warga sekolah. Sebagai supervisor, kepala sekolah berkewajiban untuk memberikan pembinaan atau bimbingan kepada para guru dan tenaga kependidikan serta administrator lainnya. Namun, sebelum memberikan pembinaan dan bimbingan kepada orang lain maka kepala sekolah harus membina dirinya sendiri. Peran kepala sekolah di kedua SMP Negeri tersebut ditunjukkan dalam pelaksanaan kegiatan yang bersifat akademik, dan kegiatan sosial kemasyarakatan lainnya. Sebagai contoh misalnya, dalam pelaksanaan kegiatan proses pembelajaran dengan membagi pengampu mata pelajaran sesuai dengan bidang keilmuannya, pembagian pembimbingan kegiatan siswa dilakukan dengan asas keadilan, transparansi (keterbukaan), dan pemenuhan jam pembelajaran guru sebagai profesi pendidik. Demikian juga, dengan kegiatan sosial kemasyarakatan dan atau kegiatan ekstrakurikuler lainnya disesuaikan dengan kemampuan masing-masing secara transparan. Kepala sekolah selalu memonitor, dan bahkan dalam pelaksanaan shalat berjamaah di masjid sekolah terkadang menjadi imam shalat yang diatur secara bergiliran dengan guru/karyawan lainnya. Hasil evaluasi kegiatan selalu diikuti oleh kepala sekolah dan apabila ditemukan permasalahan, maka kepala sekolah selalu memberikan bimbingan secara bijaksana untuk membantu pemecahannya dengan baik. Pola pembimbingan yang diperankan kepala sekolah tersebut ternyata dapat diterima oleh warga sekolah dengan baik, dan bahkan menjadikan kultur sekolah menjadi kondusif dan mampu menggerakkan semua warga sekolah dalam mengimplementasikan nilai-nilai karakter yang baik. Peran kepala sekolah sebagai pendorong dalam arti bahwa kepala sekolah mampu memberikan dorongan kepada semua warga sekolah untuk melaksanakan kegiatan program sekolah sesuai dengan visi dan misinya. Demikian juga dalam hal mengimplementasikan program sekolah yang berkarakter baik yang berkaitan dengan nilai-nilai religius maupun nilai-nilai kebangsaan. Kepala sekolah selalu menganjurkan dan mendorong warga sekolah misalnya kepada guru, karyawan, dan siswa dengan cara mengikuti peraturan dan tata tertib sekolah.

Jika dikaji lebih lanjut keterkaitan prinsip dasar yang dikembangkan oleh kepala sekolah di kedua SMP Negeri tersebut serta perannya dalam pelaksanaan implementasi pendidikan karakter di sekolah dengan kajian teori yang telah diungkapkan di muka, maka pada hakikatnya selaras dengan teori yang dikemukakan oleh Thomas Lickona (moral knowing, moral feeling, dan moral action) dan oleh Ki Hajar Dewantara dengan filosofinya "tut wuri handayani" (ing ngarsa sung tuladha, ing madya mangun karsa, dan tut wuri handayani). Metode pengajaran dan pendidikan menurut Ki Hajar Dewantara adalah berdasarkan "sistem among" yaitu: asah, asih dan asuh. Metode ini meliputi: kepala, hati dan panca- 
indera (educate the head, the heart, and the hand).

\section{Peran Guru}

Guru memiliki peran penting dalam mentransformasikan ilmu pengetahuan, sikap dan perilaku kepada peserta didik. Sikap dan perilaku guru di kedua SMP Negeri tersebut memiliki pengaruh yang positif terhadap proses pembentukan nilai-nilai karakter yang ditanamkan pada siswa, baik yang berkaitan dengan aspek kognitif (pengetahuan), afektif (sikap), dan psikomotorik (perilaku). Sikap dan perilaku guru tersebut dicerminkan dalam perannya sebagai: (1) pendidik, (2) pengasih, dan (3) pengasuh. Peran guru di kedua SMP Negeri 8 dan SMP Negeri 9 Purwokerto tersebut memiliki relevansi dengan teori yang diajarkan Ki Hadjar Dewantara dalam proses pembelajaran yang didasarkan pada metode sistem among (asih, asah, dan asuh). Ki Hajar Dewantara telah menggariskan pentingnya peranan guru dalam proses pendidikan dengan ungkapkan: Ing ngarsa sung tuladha berarti di depan memberi teladan. Ing madya mbangun karsa berarti di tengah menciptakan peluang untuk berprakarsa. Asas ini memperkuat peran dan fungsi guru sebagai mitra setara (di tengah), serta sebagai fasilitator (menciptakan peluang). Tut wuri handayani artinya dari belakang memberikan dorongan dan arahan. Hal ini mempunyai makna yang kuat tentang peran dan fungsi guru.

Para guru perlu berperan sebagai pendorong atau motivator. Peran guru sebagai mitra juga tersirat dalam asas tut wuri handayani. Fungsi pembimbing dan pendorong tidak menempatkan para guru pada hierarki teratas dalam pembelajaran. Selain perilaku tegas, guru pada saat mengajar di kelas juga menyampaikan pesan-pesan moral pada siswa untuk selalu jujur, bertanggung jawab, meningkatkan kedisiplinan, peka terhadap lingkungan, bekerjasama dan peduli sosial serta toleransi kepada siapapun. Seperti apa yang dikatakan Lickona, (2012, p.112); yang menegaskan bahwa seorang guru harus memiliki kekuatan untuk menanamkan nilai-nilai dan karakter pada anak, setidaknya dengan tiga cara yaitu: (1) Guru dapat menjadi seseorang penyayang yang efektif, menyayangi dan menghormati murid-murid, membantu mereka meraih sukses di sekolah, membangun kepercayaan diri mereka, dan membuat mereka mengerti apa itu moral dengan melihat cara guru mereka memperlakukan mereka dengan etika yang baik; (2) Guru dapat menjadi seorang model, yaitu orang-orang yang beretika yang menunjukan rasa hormat dan tanggung jawabnya yang tinggi, baik di dalam maupun di luar kelas. Guru pun dapat memberi contoh dalam hal-hal yang berkaitan dengan moral beserta alasannya, yaitu dengan cara menunjukkan etikanya dalam bertindak di sekolah dan di lingkungannya; dan (3) Guru dapat menjadi mentor yang beretika, memberikan instruksi moral dan bimbingan melalui penjelasan, diskusi di kelas, bercerita, pemberian motivasi personal, dan memberikan umpan balik yang korektif ketika ada siswa yang menyakiti temannya atau menyakiti dirinya sendiri.

\section{Peran Siswa}

Siswa sebagai subjek didik dan sebagai pelaku kegiatan di sekolah memiliki peran yang positif dalam proses pengimplementasian implementasi pendidikan karakter di sekolah pada SMP Negeri 8 dan SMP Negeri 9 Purwokerto. Sebagai subjek didik, maka yang dilakukan oleh siswa adalah menerima materi pelajaran, menerima nasihat-nasihat guru selama proses pembelajaran berlangsung baik melalui kegiatan intrakurikuler maupun ekstrakurikuler, melaksanakan tata tertib sekolah dengan penuh tanggung jawab, disiplin dalam menerima tugas materi pelajaran dari guru, dan berperilaku yang baik. Sedangkan sebagai pelaku kegiatan, berarti siswa ikut berperan aktif untuk mendukung kegiatan yang diprogramkan sekolah misalnya melalui kegiatan kebersihan, perlombaan bidang studi maupun olah raga, bakti sosial, kegiatan minat dan bakat, dan peringatan hari besar lainnya. Keefektifan implementasi pendidikan karakter di sekolah juga diwujudkan dalam bentuk aktivitas yang dilakukan oleh siswa dalam kehidupan sehari-hari di sekolah baik dalam proses pembelajaran (intrakurikuler) maupun dalam pelaksanaan kegiatan ekstrakurikuler sekolah. Berikut ini diuraikan tentang implementasi pendidikan karakter oleh siswa di SMP Negeri 8 dan di SMP Negeri 9 Purwokerto meliputi: sikap religus yaitu dengan melaksanakan shalat lima waktu, sholat dhuha, tadarus al-Qur'an setiap pagi di sekolah. Karakter peduli sosial, ditunjukkan oleh siswa dengan menjenguk teman siswa 
yang sedang sakit, serta ikut meringankan beban yang lagi sakit dengan mengumpulkan uang sekedar membeli buah tangan. Kegiatan kepedulian sosial juga dilakukan dengan mengikuti kegiatan PMR berupa membantu orang lain, termasuk donor darah. Penerapan nilai kejujuran yang ditunjukkan siswa antara lain adalah pada saat mengerjakan soal-soal ulangan sekolah. Penerapan nilai tanggung jawab ditunjukkan oleh siswa dalam melaksanakan tata tertib sekolah. Tata tertib sekolah merupakan peraturan yang sangat penting yang harus ditaati siswa dengan penuh tanggung jawab. Tata tertib sekolah di samping membentuk perilaku kedisiplinan siswa juga mengajarkan pada siswa untuk bertanggung jawab dan mematuhinya. Bekerja keras, ditunjukkan oleh siswa pada saat mengerjakan PR yang diberikan guru dan harus dapat diselesaikan tepat waktu. Siswa menghargai waktu sehingga mampu menyelesaikan penugasan dengan baik.

Nilai-nilai karakter ini sangat penting karena berpengaruh terhadap pembentukan karakter siswa bekerja keras dan tidak mudah menyerah. Kedisiplinan merupakan unsur penting bagi pembentukan karakter siswa, sebab tanpa kedisiplinan seseorang, pekerjaan akan terlambat dapat diselesaikan. Dalam kegiatan proses belajar mengajar di dalam kelas dapat di ditunjukkan oleh siswa berupa: ketepatan waktu belajar, ketepatan dalam mengerjaan soal-soal penugasan, dan ketepatan dalam mengakhiri proses pembelajaran. Pembentukan karakter siswa tidak hanya dilakukan melalui kegiatan-kegiatan di dalam sekolah atau dikenal dengan kegiatan intrakurikuler tetapi juga dilakukan melalui kegiatan ekstrakurikuler. Implementasi pendidikan karakter melalui kegiatan ekstrakurikuler, terutama yang dilakukan oleh siswa-siswa antara meliputi, (a) kegiatan Baca Tulis Alquran (BTA) dan shalat dhuhur berjamaah, (b) kegiatan olahraga, (c) kegiatan Pramuka, dan (d) kegiatan PMR. Dapat disimpulkan bahwa peran siswa dalam pelaksanaan imple-mentasi pendidikan karakter yang dilakukan di SMP Negeri 8 dan SMP Negeri 9 Purwokerto bila ditinjau dari perspektif teori nampaknya memiliki kesamaan sebagaimana teori yang dikemukakan oleh Lickona yakni moral knowing, moral feeling, dan moral action, yang pada pratiknya menunjukkan bahwa warga sekolah telah memiliki pemikiran yang diimplementasikan dalam ke- tiga tahap tersebut dengan sikap dan perilaku setiap hari di sekolah melalui keteladanan atau contoh pada siswa. Hal tersebut sesuai dengan pendapat Pestalozzi dalam Heafford (1976, p.65) yang mengatakan "The language of morality could not be taught by word of mouth, it had to be taught by example. Practice, not preaching was the basis of moral education". Pernyataan tersebut mengandung makna bahwa pembentukan karakter peserta didik tidak dapat dilakukan dengan pengajaran melalui kata-kata tetapi seyogyanya melalui contoh atau diimplementasikan oleh pemberi teladan sehingga peserta didik dapat melihat dan mengamati secara langsung hal-hal yang harus dilakukan, yang berdasarkan pada pendidikan moral.

\section{Aktualisasi atau Perwujudan Nilai-nilai Karakter dalam Implementasi Pendidikan Karakter di SMP Negeri 8 dan SMP Negeri 9 Purwokerto}

Aktualisasi atau perwujudan nilai-nilai karakter pada hakikatnya mengacu pada program pilot projek yang dicanangkan oleh Kemdikbud sebagai upaya untuk membangun sekolah yang berbasis karakter berwawasan kebangsaan, dengan menerapkan prinsip ABITA meliputi 18 (delapan belas) nilai karakter. Aktualisasi nilai-nilai pendidikan karakter yang selaras dengan nilai kebangsaan Negara Republik Indonesia adalah berdasarkan pada falsafah negara Pancasila. Nilai-nilai tersebut perlu ditumbuhkembangkan dalam proses pendidikan pada siswa sejak dini, karena hal tersebut sebagai dasar negara yang banyak mengandung nilai-nilai yang menjadi ciri khas bangsa dan masyarakat Indonesia. Nilai-nilai yang tercermin dalam setiap sila dalam Pancasila yang dapat dijadikan dasar, pandangan dan pedoman berperilaku bangsa dan masyarakat Indonesia.Nilai-nilai karakter yang diaktualisasikan oleh warga sekolah di SMP Negeri 9 Purwokerto mengacu pada prinsip ABITA (Aku Bangga Indonesia Tanah Airku) yang meliputi 18 nilai karakter, yakni: (1) nilai religius, (2) demokratis, (3) jujur, (4) tanggung jawab, (5) disiplin, (6) peduli lingkungan, (7) peduli sosial, (8) kerja keras, (9) mandiri, (10) cinta tanah air, (11) semangat kebangsaan, (12) rasa ingin tahu, (13) gemar membaca, (14) menghargai prestasi, (15) cinta damai, (16) bersahabat/komunikatif, (17) toleran, dan (18) kreatif. 
Tabel 1. Rekapitulasi Bentuk Aktualisasi Nilai-nilai Karakter dalam Implementasi Pendidikan Karakter di SMP Negeri 8 dan SMP Negeri 9 Purwokerto.

\begin{tabular}{clcc}
\hline No & Aspek Nilai Karakter & $\begin{array}{c}\text { IPK } \\
\text { Kepala Sekolah, Guru, dan } \\
\text { Siswa di SMPN 8 Purwokerto }\end{array}$ & $\begin{array}{c}\text { IPK } \\
\text { Kepala Sekolah, Guru, dan } \\
\text { Siswa di SMPN 9 Purwokerto }\end{array}$ \\
\hline 1. & Religius & Ya & Ya \\
2 & Kejujuran & Ya & Ya \\
3 & Tanggung Jawab & Ya & Ya \\
4 & Disiplin & Ya & Ya \\
5 & Peduli Sosial & Ya & Ya \\
6 & Peduli Lingkungan & Tidak & Ya \\
7 & Kerja Keras & Tidak & Ya \\
8 & Mandiri & Ya & Ya \\
9 & Cinta Tanah Air & Tidak & Ya \\
10 & Semangat Kebangsaan & Tidak & Ya \\
11 & Rasa Ingin Tahu & Tidak & Ya \\
12 & Gemar Membaca & Ya & Ya \\
13 & Menghargai Prestasi & Ya & Ya \\
14 & Cinta Damai & Ya & Ya \\
15 & Demokratis & Ya & Ya \\
16 & Bersahabat/ Komunikatif & Tidak & Ya \\
17 & Toleransi & Ya & Ya \\
18 & Kreatif & Ya & \\
\hline
\end{tabular}

Sumber: Data Primer hasil penelitian yang diolah.

Implementasi pendidikan karakter di SMP Negeri 8 Purwokerto menekankan pada aktualisasi 12 nilai karakter yang berbasis religius dan diperankan oleh semua warga sekolah dengan berkomitmen tinggi. Sedangkan implementasi pendidikan karakter di SMP Negeri 9 Purwokerto menekankan pada aktualisasi penerapan prinsip ABITA (Aku Bangga Indonesia Tanah Airku) yang meliputi 18 nilai karakter, yang secara terinci dapat dilihat pada rekapitulasi data dalam Tabel 1 .

\section{Persamaan dan Perbedaan dalam Implementasi Nilai-nilai Karakter di SMP Negeri 8 dan SMP Negeri 9 Purwokerto}

Adapun perbedaanya dalam penerapan implementasi pendidikan karakter di kedua sekolah tersebut adalah dalam hal mengaktualisasikan model proses pendidikan karakter dalam pembentukan kultur di sekolah, proses pembentukan kultur sekolah yang berwawasan karekter di SMP Negeri 9 Purwokerto menunjukkan lebih terprogram dan terintegrasi ke dalam kurikulum dibandingkan dengan yang ada di SMP Negeri 8. Hal tersebut disebabkan karena di SMP Negeri 9 Purwokerto merupakan pilot projek dari Kemendikbud sebagai salah satu sekolah yang ditetapkan sebagai model pelaksanaan implementasi pendidikan karakter untuk tingkat SMP. Sebagai salah satu sekolah yang dijadikan pilot projek tentu saja di dalam memilih nilai-nilai karakter peserta didik harus dimasukkan ke dalam kurikulum sekolah dan berbasis ABITA yang memuat 18 nilai-nilai karakter dalam proses pembentukkan kultur sekolah. Sedangkan di SMP Negeri 8 Purwokerto, dari 18 nilai-nilai karakter tersebut yang sangat menonjol diterapkan hanya meliputi 12 nilai karakter saja yaitu meliputi nilai-nilai yang telah disebutkan di atas, dan yang 6 nilai karakter tidak nampak secara eksplisit diterapkan pada pembentukan kultur sekolah yang berkarakter, meskipun secara implisit sebenarnya sudah ada di dalamnya, seperti misalnya penerapan nilai-nilai rasa ingin tahu, cinta tanah air, bersahabat atau komunikatif, dan semangat kebangsaan. Hal tersebut disebabkan, menurut pandangan kepala sekolah bahwa pada tahap awal implementasi pendidikan karakter difokuskan pada penanaman nilainilai religius, dan apabila nilai-nilai religius itu sudah dipahami dan dilaksanakan oleh 
warga sekolah utamanya siswa maka nilainilai karakter lainnya akan mudah untuk diimplementasikan di sekolah. Meskipun di kedua sekolah tersebut memiliki perbedaan dalam mengimplementasikan atau mengaktualisasikan komponen dalam implementasi pendidikan karakter, tetapi dalam proses pemikirannya ternyata di kedua sekolah tersebut juga sama-sama mengacu pada kerangka teori yang dikembangkan oleh Thomas Lickona dan Ki Hajar Dewantara. Teori yang dikembangkan Thomas Lickona yakni moral knowing, moral feeling, and moral action menunjukkan bahwa implementasi pendidikan karakter tidak akan berjalan efektif apabila para pemangku sekolah yang memiliki peran (kepala sekolah, guru, dan siswa) tidak memiliki pengetahuan yang cukup tentang moralitas, perasaan dan hati bermoral, serta contoh perilaku bermoral. Kepala sekolah, guru, dan siswa dengan pengetahuannya, perasaannya, dan perilaku bermoral harus mampu memberikan contoh keteladanan dalam kehidupan sehari-hari sesuai dengan nilai-nilai karakter dan moral yang dikembangkan di sekolah, dan Ki Hajar Dewantara yang terkenal dengan falsafahnya mengajarkan yaitu: Ing Ngarsa SungTuladha, Ing Madya Mangun Karsa, dan Tutwuri Handayani. Lebih lanjut Ki Hadjar Dewantara menginginkan bahwa pendidikan Indonesia harus mencerminkan nilai-nilai kebangsaan sendiri, jangan meniru bangsabangsa lain karena berbeda perspektifnya. Pendidikan harus bertumpu pada penguatan nalar dalam berpikir dan bermoral, beradab, dan memiliki kepekaan yang tinggi terhadap kepentingan bangsa di atas kepentingan kerdil dan sempit. Pendidikan menurut Ki Hadjar Dewantara adalah suatu hal yang mampu memberikan sumbangsih besar bagi perubahan bangsa ke depan, baik secara intelektual, sosial, maupun politik. Pendidikan diupayakan dapat membentuk karakter bangsa yang mandiri, tidak menjadi bangsa yang cengeng, selalu minta bantuan kepada bangsa lain.

Atas dasar hal tersebut, sebaiknya sekolah-sekolah yang akan mengembangkan kultur sekolah yang berkarakter melalui implementasi pendidikan karakter seyogyanya perlu memahami kerangka dasar filosofis dari kedua tokoh tersebut, serta menyesuaikan dengan program pilot proyek yang dikembangkan oleh Kemendikbud yang diaktualisasikan kedalam 18 nilai-nilai karakter (prinsip
ABITA) secara memadai, sehingga proses pembentukan kultur sekolah yang berkarakter akan bejalan secara efektif sesuai dengan tujuan pendidikan nasional. Berikut lebih jelasnya diuraikan mengenai perbedaan dan persamaan implementasi pendidikan karakter di dua sekolah:

Pertama, Aspek Reformasi Kurikulum. Di SMP Negeri 8 Purwokerto pada aspek kurikulum menunjukkan belum adanya kurikulum yang jelas tentang implementasi pendidikan karakter (baru sekadar wacana). Sekolah sudah mulai mengimplementasikan nilai-nilai karakter yang lebih bernuansa religius dalam kegiatan di sekolah baik ketika pembelajaran, bergaul di lingkungan sekolah maupun kegiatan ekstrakurikuler. Sedangkan SMP Negeri 9 Purwokerto implementasi pendidikan karakter di sekolah tersebut merupakan pilot project dari PERMENDIKBUD sebagai sekolah yang mengimplementasikan nilai-nilai pendidikan karakter. Implementasi pendidikan karakter berbasis ABITA (Aku Bangga Indonesia Tanah Airku).

Kedua, Aspek Pembelajaran. Di SMP Negeri 8 Purwokerto guru turut berperan dalam mengimplementasikan pendidikan karakter, khususnya guru mata pelajaran PKn, Pendidikan Agama Islam, dan IPS. Peran mereka yakni mengintegrasikan pada sub pokok pembahasan yang sesuai dengan nilai karakter yang ada. Misal: dalam pembelajaran Pendidikan Agama Islam ada materi mengenai memahami asmaul khusna. Sedangkan di SMP Negeri 9 Purwokerto guru turut berperan dalam memimplementasikan pendidikan karakter, khususnya guru mata pelajaran PKn, Pendidikan Agama Islam, dan IPS. Peran mereka yakni mengintegrasikan pada subpokok pembahasan yang sesuai dengan nilai karakter yang ada. Misal: dalam pembelajaran Pendidikan Agama Islam ada materi mengenai shalat berjamaah.Untuk mengamalkannya maka di sekolah tersebut di implementasikan shalat berjamaah setiap shalat dhuhur.

Ketiga, Aspek Kegiatan Ekstrakurikuler. Di SMP Negeri 8 Purwokerto dengan adanya kegiatan ekstrakurikuler yang didalamnya mengandung unsur-unsur implementasi nilai-nilai pendidikan karakter, meliputi PMR, Pramuka, Ta'lim Putri, Baca Tulis Alquran, dan olah raga (Sepak bola, Voli). Dalam kegiatan ektrakurikuler tersebut nilai karakter yang dapat diimplementasikan adalah 
tanggung jawab, komunikatif, kejujuran, religius, peduli sosial, menghargai prestasi, kreatif, mandiri dan disiplin. Sedangkan di SMP Negeri 9 Purwokerto dengan adanya kegiatan ekstrakurikuler yang di dalamnya mengandung unsur-unsur implementasi nilainilai pendidikan karakter, meliputi PMR, Pramuka, Baca Tulis al-Qur'an dan olah raga (Sepak bola, Voli). Dalam kegiatan ektrakurikuler tersebut nilai karakter yang dapat diimplementasikan adalah tanggung jawab, komunikatif, kejujuran, religius, peduli sosial, menghargai prestasi, kreatif, mandiri, dan disiplin.

\section{SIMPULAN DAN SARAN}

\section{Simpulan}

Impelementasi pendidikan karakter yang dilaksanakan di SMP Negeri 8 dan SMP Negeri 9 Purwokerto, dilakukan dengan sistem terpadu melalui pola kegiatan intrakurikuler dan ekstrakurikuler. Keterpaduan sistem pola tersebut mengharuskan pihak sekolah merancang kegiatan ekstrakurikuler sekolah yang mendukung dan melengkapi penanman nilai-nilai karakter dan moral yang diajarkan guru di dalam kelas.

Peran kepala sekolah, guru, dan siswa dalam implementasi pendidikan karakter yang dilaksanakan di SMP Negeri 8 dan SMP Negeri 9 Purwokerto, yang diwujudkan dalam bentuk peran masing-masing, memiliki pengaruh yang positif terhadap pembentukan nilainilai karakter bagi warga sekolah.

Peran Kepala Sekolah.

Beberapa peran yang sangat dominan yang diunjukkan oleh kepala sekolah dalam mengimplementasikan pendidikan karakter di sekolah, yaitu sebagai: (1) motivator, (2) pemberi contoh keteladanan, (3) pelindung, (4) penggerak kegiatan, (5) perancang kegiatan, (6) pendorong, dan (7) pembimbing. Peran kepala sekolah di kedua SMP Negeri tesebut ditunjukkan dalam pelaksanaan kegiatan yang bersifat akademik dan kegiatan sosial kemasyarakatan lainnya.

\section{Peran Guru.}

Guru memegang peranan yang sangat strategis terutama dalam membentuk karakter serta mengembangkan potensi siswa. Sikap dan perilaku guru dalam keseharian di dalam kelas, di sekolah maupun di luar lingkungan sekolah mencerminkan sikap dan perilaku yang dapat diteladani oleh peserta didik, seperti datang tepat waktu, rapi dalam berpakaian, datang di sekolah lebih awal, peduli akan kebersihan lingkungan sekolah, dan tegas memberikan sangsi pada peserta didik yang melanggar tata tertib. Sikap dan perilaku guru tersebut dicerminkan dalam perannya sebagai: (1) pendidik, (2) pengasih, dan (3) pengasuh. Peran guru di kedua SMP Negeri 8 dan SMP Negeri 9 Purwokerto tersebut memiliki relevansi dengan teori yang diajarkan Ki Hadjar Dewantara dalam proses pembelajaran yang didasarkan pada metode sistem among (asih, asah, dan asuh). Sikap dan perilaku guru di kedua SMP Negeri tersebut memiliki pengaruh yang positif terhadap proses pembentukan nilai-nilai karakter yang ditanamkan pada siswa, baik yang berkaitan dengan aspek kognitif (pengetahuan), afektif (sikap), maupun psikomotorik (perilaku). Pendekatan pola asah, asih, dan asuh yang dilakukan guru di kedua SMP Negeri tersebut ternyata memberikan manfaat yang besar bagi interaksinya dengan peserta didik di mana peserta didik sangat dekat dengan guru sehingga peserta didik sangat menyukai pelajaran yang diajarkan oleh guru.

\section{Peran Siswa.}

Siswa sebagai subjek didik dan sebagai pelaku kegiatan di sekolah memiliki peran yang positif dalam proses pengimplementasian pendidikan karakter di SMP Negeri 8 dan SMP Negeri 9 Purwokerto. Sebagai sobyek didik, maka yang dilakukan oleh siswa adalah menerima materi pelajaran, menerima nasihat-nasihat guru selama proses pembelajaran berlangsung baik melalui kegiatan intrakurikuler maupun ekstrakurikuler, melaksanakan tata tertib sekolah dengan penuh tanggung jawab, disiplin dalam menerima tugas materi pelajaran dari guru, dan berperilaku yang baik. Sedangkan sebagai pelaku kegiatan, berarti siswa ikut berperan aktif untuk mendukung kegiatan yang diprogramkan sekolah misalnya melalui kegiatan kebersihan, perlombaan bidang studi maupun olah raga, bakti sosial, kegiatan minat dan bakat, dan peringatan hari besar lainnya. Implementasi pendidikan karakter yang dilakukan oleh siswa SMP Negeri 8 dan SMP Negeri 9 Pur- 
wokerto pada dasarnya sangat beragam dan sangat tergantung dari karakteristik peserta didik. Namun demikian nilai-nilai kebangsaan dan nilai religius merupakan fondasi dasar yang dipraktikkan di sekolah, yang mengacu pada prinsip ABITA (Aku Bangga Indonesia Tanah Airku) yang dikembangkan Kemdikbud sebagai kebijakan nasional dalam membangun pendidikan karakter peserta didik.

Aktualisasi atau bentuk implementasi pendidikan karakter di SMP Negeri 8 dan SMP Negeri 9 Purwokerto dapat disimpulkan bahwa perwujudan nilai-nilai karakter pada hakikatnya mengacu pada program pilot proyek yang dicanangkan oleh Kemdikbud sebagai upaya untuk membangun sekolah yang berbasis karakter berwawasan kebangsaan dan religius, dengan menerapkan prinsip ABITA yang meliputi 18 (delapan belas) nilai karakter. Aktualisasi nilai-nilai pendidikan karakter yang selaras dengan nilai kebangsaan Negara Republik Indonesia adalah berdasarkan pada falsafah Pancasila. Nilai-nilai karakter yang diaktualisasikan oleh warga sekolah mengacu pada prinsip ABITA (Aku Bangga Indonesia Tanah Airku) berwawasan kebangsaan yang meliputi 18 nilai karakter, yakni: (1) nilai religius, (2) demokratis, (3) jujur, (4) tanggung jawab, (5) disiplin, (6) peduli lingkungan, (7) peduli sosial, (8) kerja keras, (9) mandiri, (10) cinta tanah air, (11) semangat kebangsaan, (12) rasa ingin tahu, (13) gemar membaca, (14) menghargai prestasi, (15) cinta damai, (16) bersahabat/komunikatif, (17) toleran, dan (18) kreatif.

Dalam mengimplementasikan Pendidikan Karakter Di SMP Negeri 8 dan SMP Negeri 9 Purwokerto memiliki persamaan dan perbedaan. Berdasarkan hasil pembahasan dan kajian di muka dapat disimpulkan bahwa pada dasarnya di kedua sekolah tersebut memiliki kesamaan dalam mengimplementasikan praktik pendidikan karakter di sekolah, yaitu terutama dalam mengaktualisasikan 12 komponen nilai karakter sebagai berikut yang meliputi: penanaman nilai-nilai religius, jujur, kedisiplinan, toleran, kerja keras, kratif, mandiri, demokratis, menghargai prestasi, cinta damai, gemar membaca, peduli lingkungan, peduli sosial, peduli lingkungan, dan tanggung jawab. Adapun perbedaanya dalam implementasi pendidikan karakter di kedua sekolah tersebut adalah dalam hal mengaktualisasikan proses pendidikan karakter dalam pem- bentukan kultur di sekolah, yang menunjukkan bahwa di SMP Negeri 9 Purwokerto lebih terprogram dan terintegrasi ke dalam kurikulum dibandingkan dengan yang ada di SMP Negeri 8 Purwokerto. Hal tersebut disebabkan karena di SMP Negeri 9 Purwokerto merupakan pilot proyek dari Kemdikbud sebagai salah satu sekolah yang ditetapkan sebagai model pelaksanaan implementasi pendidikan karakter untuk tingkat SMP. Sebagai salah satu sekolah yang dijadikan pilot proyek tentu saja di dalam mengisi nilai-nilai karakter peserta didik harus di masukkan kedalam kurikulum sekolah dan menerapkan prinsip ABITA yang memuat 18 nilai-nilai karakter dalam proses pembentukkan kultur sekolah. Meskipun di kedua sekolah tersebut memiliki perbedaan dalam mengimplementasikan komponen nilai karakter dalam implementasi raktik pendidikan karakter di sekolah, tetapi dalam proses pemikirannya ternyata di kedua sekolah tersebut juga memiliki ke-samaan pada kerangka teori yang dikembangkan oleh Thomas Lickona dan Ki Hajar Dewantara.

\section{Saran}

Bagi Kemdikbud, Pemda, dan Dinas Pendidikan dan Kebudayaan diharapkan hasil penelitian ini dapat digunakan sebaga dasar pertimbangan untuk membuat kebijakan khususnya dalam implementasikan pendidikan karakter di sekolah, yaitu dengan menerapkan Prinsip ABITA berwawasan kebangsaan yang Religius.

Bagi pihak sekolah (terutama kepala sekolah, guru, dan karyawan) dalam menerapkan aturan tata tertib sekolah yang mendukung implementasi pendidikan karakter berbasis ABITA harus dilakukan secara konsekuen dengan prinsip keadilan dan untuk penjenjangan karier warga sekolah.

Bagi siswa diharapkan mampu menyesuaikan diri dengan peraturan tata tertib sekolah yang diberlakukan, termasuk dalam kaitannya dengan sistem penilaian prestasi akademik maupun prestasi non-akademik yang mengacu pada nilai-nilai pendidikan karakter dan moral yang diterapkan oleh pihak sekolah.

\section{Daftar Pustaka}

Dewantara, Ki Hadjar. (1955). "Pangkalpangkal roch taman siswa" dalam 
buku Peringatan taman siswa tahun 1922-1952. Yogyakarta: Majelis Luhur Taman Siswa.

Dewantara, Ki Hadjar. (1961). Ki Hadjar Dewantara: Bagian I Pendidikan . Yogyakarta: Majelis Luhur Persatuan Taman Siswa.

Dewantara, Ki Hadjar. (1980). Karya Ki Hadjar Dewantara: Bagian II A kebudayaan. Yogyakarta: Majelis Luhur Persatuan Taman Siswa.

Dewantara, Ki Hadjar. (2008). “Kebangkitan pendidikan nasional, menggali butirbutir pemikiran pendidikan Ki HadjarDewantara untuk memaknai kebangkitan nasional" kumpulan tulisan. Yogyakarta: Perpustakaan Puro Pakualamaman.

Hasan M.T. (2003). Islam dan masalah sumber daya manusia. Jakarta: Lantabora Press.

Hamengkubuwono X, Sri Sultan. (2012). Membangun insan yang berkarakter dan bermartabat, naskah pidato dalam rangka peringatan diesnatalis 6 windu UNY. Yogyakarta.

Lickona, T. (1991). Educating for character:how our schools can teach respect and responsibility.New York: Bantam Books.

Lickona, T. (2010). "Thomas Lickona, talks about character education". Proquest education journals. Vol. 14 no. 7, pp 48-49.

Milles, M. B \& Huberman, A. M. (2007). Analisis data kualitatif. Jakarta: Universitas Indonesia Press.

Parkay, F. W \& Beverly, H. S. (1998). Becoming a teacher. Boston-Singapore: Allen and Bacon.

Pemerintah Republik Indonesia (2010), Kebijakan Nasional, Pembangunan Karakter Bangsa 2010-2025.

Undang-undang Republik Indonesia No. 20 Tahun 2003, tentang Sistem Pendidikan Nasional. Bandung: Citra Umbara.

Undang-undang dan Peraturan Pemerintah RI tentang Pendidikan, Direktorat Jenderal Pendidikan Agama Islam, DEPAG RI Tahun 2006.

Zamroni. (2011a.). Dalam Darmiyati edt. Strategi dan model implementasi pendidikan karakter di sekolah. Yogyakarta: UNY Press. 